\title{
Analysis of incidence of caesarean sections in primigravida
}

\author{
Suyujna D. Joshi, Rajeshwari Rai*, Ruksar Banu, Jayasakthi G.
}

Department of Obstetrics and Gynecology, Post Graduate District Hospital, Ballari, Karnataka, India

Received: 02 January 2021

Revised: 10 February 2021

Accepted: 11 February 2021

\section{*Correspondence:}

Dr. Rajeshwari Rai,

E-mail: rajeerai2111@gmail.com

Copyright: ( $)$ the author(s), publisher and licensee Medip Academy. This is an open-access article distributed under the terms of the Creative Commons Attribution Non-Commercial License, which permits unrestricted non-commercial use, distribution, and reproduction in any medium, provided the original work is properly cited.

\section{ABSTRACT}

Background: Current study was conducted to determine the incidence of caesarean sections in primigravida.

Methods: A total number of 1698 primigravidas were admitted in the department of DNB district hospital Ballari, out of which 501 primigravidas who underwent caesarean section were included in the study.

Results: Caesarean section rate in primigravida was observed to be $29.5 \%, 55 \%$ of women were from rural areas and $45 \%$ from urban areas, $69.9 \%$ women belonged to lower class $31.1 \%$ belonged to upper middle class, $25 \%$ were illiterate while $75 \%$ were literate.

Conclusions: Meta-analysis suggests that the occurrence of pregnancy complications differ according to fetal sex with a higher cardiovascular and metabolic load for the mother in the presence of a male fetus.

Keywords: Primigravida, Pregnancy, LSCS

\section{INTRODUCTION}

Caesarean section (CS) is an operative procedure whereby the fetuses after the end of twenty-eight weeks most widely performed surgical procedure worldwide. It was mainly evolved as a lifesaving procedure for mother and fetus during the difficult delivery. There is progressive increase in caesarean deliveries across the world both in developed as well developing countries. ${ }^{1}$ This increase in $\mathrm{C}$-section rate has become a major public health issue, because It is a burden on health system and imposes strain on families. ${ }^{2}$ With increased use of intrapartum fetal monitoring like cardiotocograph, doppler, biophysical profile in labor room the cesarean rate have been increased. Rise in identification of highrisk pregnancies, good antenatal follow up, elective induction of labor etc also adds to increase in rates of cesarean deliveries.

Aim of current study is to determine the incidence of caesarean sections in primigravida. Objectives of the current study were to analyse caesarean section in primigravida in context with; indications, ssocioeconomic status, ggestational age and mmorbidity and mortality associated with surgical procedure.

\section{METHODS}

The present study was a retrospective observational study conducted in the department of obstetrics and gynaecology, District hospital Ballari from 1 January 2019 to 31 December 2019. In current study, all primigravida women who were admitted in labour room and who fulfilled the inclusion criteria and were willing to participate were selected and analyzed for the incidence of caesarean section.

\section{Inclusion criteria}

Inclusion criterion for current study was all primi gravida's who were admitted in department of OBG and who underwent caesarean section. 


\section{Exclusion criteria}

Exclusion criteria of current study were; primigravida's who delivered vaginally, multigravida's who delivered vaginally or who underwent caesarean section.

Results were analyzed with special emphasis on incidence of caesarean section in primigravida using simple percentage-based calculations.

\section{RESULTS}

A total number of 1698 primigravidas were admitted at hospital out of which 501 primigravidas who underwent caesarean section were included in the study; caesarean section rate in primigravida was observed to be $29.5 \%$. $55 \%$ of women were from rural areas and $45 \%$ from urban areas $69.9 \%$ women belonged to lower class $31.1 \%$ belonged to upper middle class $25 \%$ were illiterate while $75 \%$ were literate. $80.8 \%$ of patients delivered between 37 to 40 weeks, $10.8 \%$ below 37 weeks and $8.4 \%$ delivered after 40 weeks. $94.4 \%$ were booked cases remaining $5.6 \%$ were unbooked cases. $18.9 \%$ babies were $<2.5 \mathrm{Kg}, 22.4 \%$ babies were above $3.5 \mathrm{Kg}$ and $58.7 \%$ babies were between 2.5 to $3.5 \mathrm{Kg}$. $57.3 \%$ babies were male babies and $42.7 \%$ were female babies, $15 \%$ of babies admitted in NICU. $12 \%$ of patients were associated with pregnancy induced hypertension, $8 \%$ with hypothyroidism and $3.1 \%$ with premature rupture of membranes. No cases of gestational diabetes admitted.

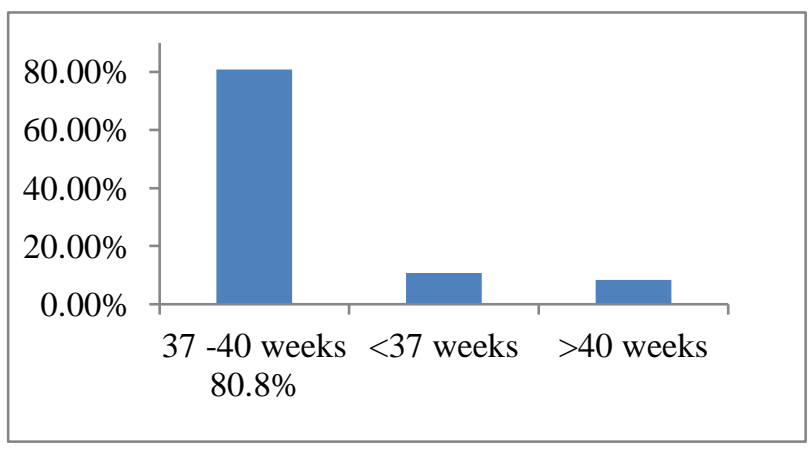

Figure 1: Distribution according to gestation age at delivery.

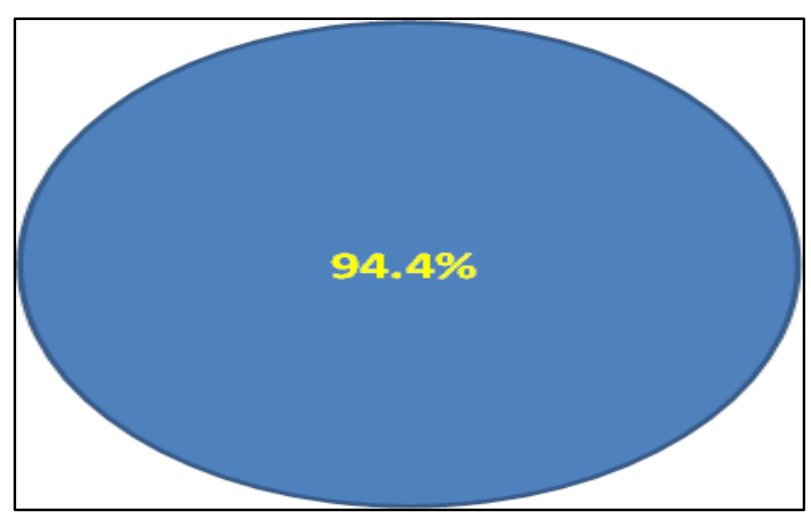

Figure 2: Booking status.
Table 1: Distribution according to age.

\begin{tabular}{|lll|}
\hline Gestation (years) & $\mathbf{N}$ & $\%$ \\
\hline $\mathbf{2 1 - 3 0}$ & 251 & 50.5 \\
\hline$\leq \mathbf{2 0}$ & 231 & 46.1 \\
\hline $\mathbf{3 0}$ & 17 & 3.4 \\
\hline
\end{tabular}

Table 2: Distribution according to indications.

\begin{tabular}{|lll|}
\hline Indications & N & $\%$ \\
\hline Fetal distress & 201 & 40.11 \\
\hline Cephalopevic disproportion & 116 & 23.1 \\
\hline Oligohydramnios & 74 & 14.7 \\
\hline Malpresentations & 45 & 9 \\
\hline Second stage arrest & 20 & 4 \\
\hline anhydramnios & 19 & 3.7 \\
\hline Non progression of labour & 10 & 1.99 \\
\hline Twins & 7 & 1.3 \\
\hline Cord prolapse & 5 & 1 \\
\hline Placenta previa & 3 & 0.59 \\
\hline Abruptio placenta & 1 & 0.2 \\
\hline
\end{tabular}

Table 3: Distribution according to birth weight.

\begin{tabular}{|c|c|c|}
\hline Birth weight (Kg) & $\mathbf{N}$ & $\%$ \\
\hline$<2.5$ & 95 & 18.9 \\
\hline $2.5-3.5$ & 295 & 58.8 \\
\hline$>3.5$ & 111 & 22.3 \\
\hline
\end{tabular}

\section{DISCUSSION}

In present study majority of primigravidas $(55 \%)$ who underwent caesarean section were from rural areas and from lower socioeconomic class $(69.9 \%), 53.4 \%$ were illiterate, $94.4 \%$ were booked cases, $50.5 \%$ patients were between age group $21-30$ years and $46.1 \%<20$ years. In present study most common indication was fetal distress (40.11\%) followed by cephalopelvic pelvic disproportion (23.1\%) and oligohydramnios (14.7\%). 58.7\% babies were between 2.5 to $3.5 \mathrm{Kg}$ and $57.3 \%$ babies born were male babies. In present study caesarean section rate in primigravida was $29.5 \%$ as compared to standard WHO recommendation of $15 \%$. Lot of referred cases were received after initial trial at $\mathrm{CHC} / \mathrm{PHC}$ by staff nurses, medical officers and general practitioners in private hospitals. Cephalopelvic disproportion was observed to be the most common indication; early marriage and early pregnancy were also important contributing factors. Belizán et al analysis showed that every year in the world there is an additional need for 0.8-3.2 million CS in low income countries were $60 \%$ of the world's births occur. ${ }^{2}$ Simultaneously, 4.0-6.2 million CS in excess are performed in middle and high income countries where $37.5 \%$ of the births occur. From a population based approach, those CS in excess are likely to be medically unjustified and should be then considered unnecessary CS. ${ }^{3-10}$ Malabary et al retrieved nationally representative CS rates from 137 countries representing more than $95 \%$ of the world annual number of births. The purpose of 
their study was to evaluate in a biological model the effect of pelvic size on cesarean delivery rates. they used young maternal age as an unbiased marker for pelvic size and compared cesarean delivery rates for each age in years from the age of 12 to 20 . They carried out study in a cohort with a sufficient number of subjects to have significant results. Their findings show that cesarean delivery rates increased with decreasing age, and that this effect was modified by birth weight, specifically macrosomia. ${ }^{11} \mathrm{Li}$ et al study showed that the overall rate of CS in mainland China was $54.90 \%$ and the most common indication for $\mathrm{CS}$ was maternal request $(28.43 \%) .{ }^{12}$ CDMR accounted for $15.53 \%$ of all deliveries and $28.43 \%$ of the CS deliveries in mainland China. The overall rate of CS in tertiary care hospitals was slightly higher than that in secondary care hospitals, probably because women with high-risk pregnancies were more likely to be admitted to tertiary care than to secondary care hospitals. This presumption is supported by the higher rate of high-risk pregnancy in the tertiary care hospitals compared with the secondary hospitals. Jagannath et al observed the most common age group in their study was 20-25 years (47\%). The incidences of primary caesarean section were $68.36 \%$. Among their study cases, $40 \%$ were booked, $17 \%$ were booked but admitted as emergency and $43 \%$ were unbooked. ${ }^{13}$

\section{Limitations}

Limitation of the current study was as it was a retrospective study all the data couldn't be collected

\section{CONCLUSION}

It can be concluded that being a tertiary care hospital, a high rate of caesarean deliveries was observed. Individualization of the indication and careful evaluation, following standardized guidelines, practice of evidencedbased obstetrics and audits in the institution, can help in limiting caesarean section rate

Funding: No funding sources

Conflict of interest: None declared

Ethical approval: The study was approved by the Institutional Ethics Committee

\section{REFERENCES}

1. Berg AO, Baird MA, Botkin JR, Driscoll DA, Fishman PA, Guarino PD, et al. National institutes of health state-of-the-science conference statement: family history and improving health. Ann Intern Med. 2009;151(12):872-7.
2. Gibbons L, Belizan JM, Lauer JA, Betran AP, Merialdi M, Althabe F. The global numbers and costs of additionally needed and unnecessary caesarean sections performed per year: overuse as a barrier to universal coverage. Available at: https://www.scienceopen.com/document?vid=a9ac3a ae-f6f3-4249-8279-f8fe80bd4829. Accessed on 20 December 2020.

3. Belizán JM, Cafferata ML, Althabe F, Buekens P. Risk of patient choice caesarean. Birth. 2006;33:1679.

4. Caughey AB, Cahill AG. Safe prevention of the primarycesarean delivery. Obstet Care Consen. 2014; 1:2-19.

5. Stanton C, Ronsmans C. Recommendations for routine reporting on indications for caesarean delivery in developing countries. Birth. 2008;35:20411.

6. Torloni MR, Betran AP, Souza JP, Widmer M, Allen $\mathrm{T}$, Gulmezoglu M, et al. Classifications for caesarean section: a systematic review. PLoS One. 2011;6: e1456.

7. Challis J, Newnham J, Petraglia F, Yeganegi M. Fetal sex and preterm birth. Placenta. 2013;34:95-9.

8. Aibar L, Puertas A, Valverde M, Carrillo MP, Montoya F. Fetal sex and perinatal outcomes. J Perinat Med. 2012;40:271-6.

9. Sheiner E, Levy A, Katz M, Hershkovitz R, Leron E, Mazor M. Gender does matter in perinatal medicine. Fetal Diagn Ther. 2004;19:366-9.

10. Bergsjø P, Maltau JM. Bleeding in the last part of pregnancy. In: Maltau BP, Molne JM, Nesheim K, eds. Obstetrics and Gynecology. 2nd ed. Norway: Gyldendal Norwegian publishing house; 2010.

11. Malabary OT, Balayla J. The effect of pelvic size on cesarean delivery. J Pediatr Adolecent Gynecol. 2012;25(3):190-212.

12. Li G, Zou L, Li C, Chen Y, Yuan Y, Wang X, Jia C, et al. Cesarean delivery rate and indications in mainland China: a cross sectional study in 2011. 2014;49(10):728-35.

13. Jagannath P, Himangshu M, Konyak P, Marak BC, Goel I. Cesarean section in the primigravid. Sch J App Med Sci. 2016;4(9):3307-11.

Cite this article as: Joshi SD, Rai R, Banu R, Jayasakthi G. Analysis of incidence of caesarean sections in primigravida. Int J Reprod Contracept Obstet Gynecol 2021;10:1433-5. 